\title{
Reactions of Precious and Inactive Metals with Acids
}

\author{
A. Sulcius ${ }^{1, *}$, S. Gilmanshina ${ }^{2}$, R. Sagitova ${ }^{2}$ \\ ${ }^{1}$ Kaunas University of Technology, Lithuania \\ ${ }^{2}$ Kazan (Volga region) Federal University, Russia \\ *Corresponding author: algirdas.sulcius@ktu.lt
}

\begin{abstract}
In chemistry, the redox reactions play an important role. While studying chemistry at the universities, much attention is paid to the problems of redox processes. One of the most important issues is the interaction of metals with solutions of strong acids. To qualitatively evaluate the possibility of dissolving a metal in strong acids, one can use the electrochemical series of metals. Metals, which are on the left side from hydrogen in electrochemical series, react with strong acids and release hydrogen. Sulfuric acid and nitric acid, depending on their concentration in the solution, react with metals, releasing a whole spectrum of gaseous products. Solution of many questions of redox reactions are addressed by memorizing responses or reaction algorithms. However, a person cannot remember everything, ones does not need. In order to help students to understand and write oxidation-reduction equations and avoid learning by heart, the authors suggest calculating the electromotive force (EMF) of redox reactions and then predicting their thermodynamic probability under standard and real conditions. In the article reactions of inactive and precious metals $(\mathrm{Cu}, \mathrm{Au}$ and $\mathrm{Pt})$ with strong acids using standard and stationary potentials of metals, which allow to calculate EMF and predict a "thermodynamically favourable" reaction without performing an experiment, are explained.
\end{abstract}

Keywords: inactive and precious metals, standard potential, stationary potential, electromotive force

Cite This Article: A. Sulcius, S. Gilmanshina, and R. Sagitova, "Reactions of Precious and Inactive Metals with Acids.” World Journal of Chemical Education, vol. 6, no. 2 (2018): 91-94. doi: 10.12691/wjce-6-2-3.

\section{Introduction}

In chemistry, the redox reactions play an important role. They cover a wide range of processes and phenomena that occur in the world around us. Therefore, it is impossible to understand the modern inorganic chemistry without examining the redox reactions. Thus, much attention is paid to the questions of redox processes during the chemistry studies at the universities.

One of the most important issues is the interaction of metals with dilute solutions of strong acids. To qualitatively evaluate the possibility of dissolving a metal in strong acids, for example, sulfuric or hydrochloric acid, one can use the electrochemical series of metals:

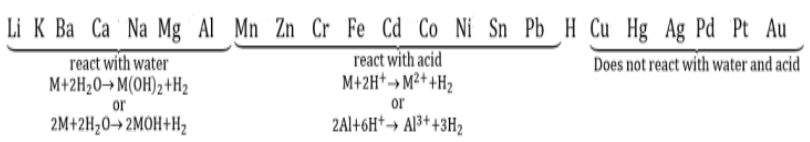

Metals, which are on the left from hydrogen in electrochemical series, react with strong acids and release hydrogen. It should be remembered that sulfuric acid and nitric acid, depending on their concentration in the solution, react with metals, releasing a whole spectrum of gaseous products [1,2].

Secondary and high school students carried out experiments testing how metals dissolve in different acids as well as investigated interaction of copper with solution of hydrochloric or sulfuric acid in the absence and presence of oxygen and its reaction with solution of hydroiodic acid in the absence of oxygen. Students were guided by a work manual and were encouraged to work in teams during experiment. Therefore, this experiment really provided a great opportunity to improve their communication skills.

Attention of secondary school students was focused only on testing the metal activity series: does a metal react or not. They were enthusiastic and admired the experiment with expressions of excitement and cheered every change of the reaction. High school students were less enthusiastic, but more inquisitive and specific in their questions. Many of them expressed great surprise that the result of the change of reaction conditions also varied with metal activity. Students also learned to predict the outcome of the redox reactions without actually carrying the experiments.

The aim of article is to explain reactions of inactive and precious metals with acids using standard and stationary potentials of metals, which allow to calculate electromotive force (EMF) and determine the possibility for the redox processes to take place.

\section{Results and Discussion}

\subsection{Reactions $\mathrm{Cu}$ with acids at different conditions}

It is known that the course of reaction of metals with acids depends on various conditions [3]. For example, in 
the absence of oxygen under real conditions copper does not react with hydrochloric acid and dilute sulfuric acid, what is indicated by the value of EMF. To simplify the calculations, $1 \mathrm{M}$ hydrochloric acid can be used and hydrogen ion activity coefficient could be considered to be $\sim 1$ :

$$
\begin{aligned}
& E_{\text {oxid. agent }}^{\circ}=E^{\circ}\left(2 \mathrm{H}^{+} / \mathrm{H}_{2}\right)-0.059 \times \mathrm{pH}[4] \\
& E_{\text {oxid. agent }}^{\circ}=0-0.059 \times 0=0 \mathrm{~V} \\
& E^{p H<7} \text { reduc.agent }\left(\mathrm{Cu}^{2+} / \mathrm{Cu}\right)=+0.15 \mathrm{~V}[2] \\
& \mathrm{E}=E_{\text {oxid.agent }}^{0}-E^{0} \text { reduc.agent } \\
& \quad=E_{\text {oxid. agent }}^{\circ}-E^{p H<7} \text { reduc.agent }\left(\mathrm{Cu}^{2+} / \mathrm{Cu}\right) \\
& =0-(+0.15)=-0.15 \mathrm{~V}
\end{aligned}
$$

The question students had was whether it is possible to create conditions under which copper can react with dilute acids. Yes, it is possible. There are some conditions:

1 ) in the presence of an oxidizing agent, for example oxygen, copper reacts not only with hydrochloric acid and sulfuric acid, but even with weak acetic acid [5]:

$$
\begin{aligned}
2 \mathrm{Cu}(\mathrm{s})+ & 2 \mathrm{CH}_{3} \mathrm{COOH}(\mathrm{aq})+\mathrm{O}_{2}(\mathrm{~g}) \rightarrow \\
& \mathrm{Cu}\left(\mathrm{CH}_{3} \mathrm{COO}\right)_{2} \times \mathrm{Cu}(\mathrm{OH})_{2}(\mathrm{~s}) .
\end{aligned}
$$

Calculation of EMF in aerated hydrochloric acid under real condition:

$$
\begin{gathered}
2 \mathrm{Cu}(\mathrm{s})+\mathrm{O}_{2}(\mathrm{~g})+4 \mathrm{HCl}(\mathrm{aq}) \rightarrow 2 \mathrm{CuCl}_{2}(\mathrm{aq})+2 \mathrm{H}_{2} \mathrm{O}(\mathrm{l}) \\
\mathrm{O}_{2}(\mathrm{~g})+4 \mathrm{H}^{+}(\mathrm{aq})+4 \mathrm{e}^{-} \rightarrow 2 \mathrm{H}_{2} \mathrm{O}(\mathrm{l}) \\
E_{\text {oxid.agent }}^{0}\left(4 \mathrm{H}^{+}+\mathrm{O}_{2} / \mathrm{H}_{2} \mathrm{O}\right)=1.23 \mathrm{~V} \\
E^{p H<7} \text { reduc.agent }\left(\mathrm{Cu}^{2+} / \mathrm{Cu}\right)=+0.15 \mathrm{~V} . \\
\mathrm{E}=E_{\text {oxid.agent }}^{0}-E_{\text {reduc.agent }}^{0} \\
=E_{\text {oxid.agent }}^{0}\left(4 \mathrm{H}^{+}+\mathrm{O}_{2} / \mathrm{H}_{2} \mathrm{O}\right)- \\
E^{p H<7} \text { reduc.agent }\left(\mathrm{Cu}^{2+} / \mathrm{Cu}\right) \\
=1.23-(+0.15)=1.08 \mathrm{~V} .
\end{gathered}
$$

Taking in account an oxygen overvoltage, which value on $\mathrm{Cu}$ is $1.05 \mathrm{~V}$, it can be concluded that $\mathrm{Cu}$ dissolves in aerated dilute acid. This is confirmed by the photo of the experiment:

Injection of oxygen into $1 \mathrm{M}$ hydrochloric acid solution (15 min)

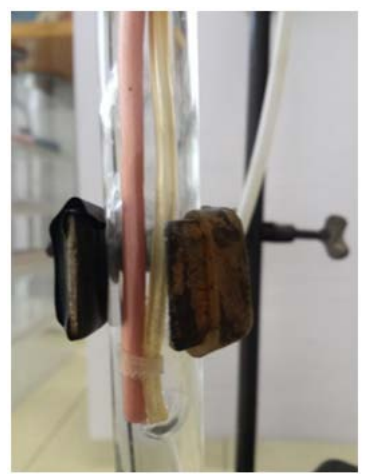

After 15 min from the start of the experiment, $2 \mathrm{M}$ sodium hydroxide solution is added
$0 \mathrm{~s}$

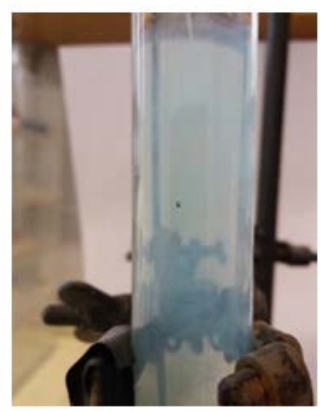

$60 s$

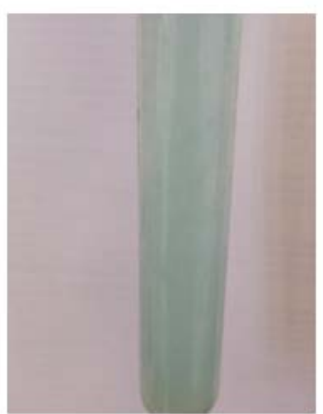

2) if there is a complexing agent [6,7]. Hydroiodic acid (example A) and hydrobromic acid (example B) can be used as one.

\section{Example A}

Unlike hydrochloric acid, hydroiodic acid can react with copper with displacement of hydrogen. The reason is the formation of a strong complex $\left[\mathrm{CuI}_{2}\right]^{-}$ion in accordance with the reaction equation:

$$
\mathrm{Cu}(\mathrm{s})+4 \mathrm{HI}(\mathrm{aq}) \rightarrow 2 \mathrm{H}\left[\mathrm{CuI}_{2}\right](\mathrm{aq})+\mathrm{H}_{2}(\mathrm{~g})
$$

To evaluate and prove the theoretical possibility of redox reaction in a solution of hydroiodic acid students made simple calculations.

For the reduction half-reaction:

$$
2 \mathrm{H}^{+}(\mathrm{aq})+2 \mathrm{e}^{-} \rightarrow \mathrm{H}_{2}(\mathrm{~g})
$$

the value of the standard electrode potential can be used in calculations if $1 \mathrm{M}$ hydroiodic acid is used, the hydrogen ion activity coefficient could be considered to be $\sim 1$ :

$$
\begin{aligned}
E_{\text {oxid. agent }}^{\circ} & =E^{\circ}\left(2 \mathrm{H}^{+} / \mathrm{H}_{2}\right)-0.059 \times \mathrm{pH}[ \\
= & 0-0.059 \times 0=0 \mathrm{~V}
\end{aligned}
$$

For the oxidation half-reaction:

$$
\mathrm{Cu}(\mathrm{s})-\mathrm{e}^{-}+2 \mathrm{I}^{-}(\mathrm{aq}) \rightarrow \mathrm{CuI}_{2}^{-}(\mathrm{aq})
$$

the potential value is calculated taking into account the concentration of simple and complex ions:

$$
\begin{aligned}
& E_{\text {red. agent }}=E\left(\mathrm{CuI}_{2}^{-} / \mathrm{Cu}\right) \\
& =E^{0}\left(\mathrm{CuI}_{2}^{-} / \mathrm{Cu}\right)+0.059 \cdot \lg \frac{\left[\mathrm{CuI}_{2}^{-}\right]}{\left[I^{-}\right]^{2}}= \\
& =E^{0}\left(\mathrm{CuI} I_{2}^{-} / \mathrm{Cu}\right)+0.059 \cdot \lg \frac{\left[\mathrm{CuI}_{2}^{-}\right]}{\left[I^{-}\right]^{2}} \cdot \frac{\left[\mathrm{Cu}^{+}\right]}{\left[\mathrm{Cu}^{+}\right]}= \\
& =E^{0}\left(\mathrm{CuI}_{2}^{-} / \mathrm{Cu}\right)+0.059 \cdot \lg \beta_{2} \cdot\left[\mathrm{Cu}^{+}\right]= \\
& =E^{0}\left(\mathrm{CuI}_{2}^{-} / \mathrm{Cu}\right)+0.059 \cdot \lg \beta_{2} \cdot \frac{\mathrm{SP}}{\left[\mathrm{I}^{-}\right]}= \\
& =E^{0}\left(\mathrm{CuI} I_{2}^{-} / \mathrm{Cu}\right)+0.059 \cdot\left(\lg \beta_{2}+\lg \frac{\mathrm{SP}}{\left[\mathrm{I}^{-}\right]}\right)= \\
& =0+0.059 \cdot(8.85-11.96)=-0.18 \mathrm{~V}
\end{aligned}
$$


where $\beta_{2}$ - instability constant of $\left[\mathrm{CuI}_{2}\right]^{-} 1.75 \cdot 10^{-9}$, $\lg \beta_{2}=8.85$ [8];

$\mathrm{SP}$ - solubility product of CuI, $1.1 \cdot 10^{-12}, \operatorname{lgSP}=11.96$ $[8,9]$;

$$
E^{\circ}\left(\mathrm{CuI}_{2}^{-} / \mathrm{Cu}\right)=0 \mathrm{~V}[10]
$$

The ionic activity of $\mathrm{I}^{-}$is assumed to be equal to the concentration, $1 \mathrm{M}$, and the activity coefficient is taken as $\sim 1.0$.

The possibility for the reaction to take place is confirmed by the calculations of the EMF:

$$
\begin{aligned}
\mathrm{E} & =E^{0}{ }_{\text {oxid.agent }}-E^{0} \text { reduc.agent } \\
& =0-(-0.18)=0.18 \mathrm{~V}>0
\end{aligned}
$$

The value of EMF indicates that this process is possible under standard conditions.

During the experiment, students found out that $\mathrm{Cu}$ grains, when dissolving in $\mathrm{HI}$, formed a white precipitate, which eventually dissolved after mixing by glass rod.

\section{Example B}

$$
\begin{aligned}
\mathrm{Cu}(\mathrm{s})+4 \mathrm{HBr}(\mathrm{aq}) \rightarrow 2 \mathrm{H}\left[\mathrm{CuBr}_{2}\right](\mathrm{aq})+\mathrm{H}_{2}(\mathrm{~g})[7] \\
\mathrm{Cu}-\mathrm{e}^{-}+2 \mathrm{Br}^{-} \rightarrow\left[\mathrm{CuBr}_{2}\right]^{-} E^{0}=0.05 \mathrm{~V}[11] \\
\mathrm{E}_{\text {red. agent }}=\mathrm{E}^{0}\left(\mathrm{CuBr}_{2}^{-} / \mathrm{Cu}\right)+0.059 \cdot\left(\lg \beta_{2}+\lg \frac{\mathrm{SP}}{\left[\mathrm{I}^{-}\right]}\right)= \\
=0.05+0.059 \cdot(5.89-8.28)=-0.09 \mathrm{~V}
\end{aligned}
$$

where $\beta_{2}$ - instability constant of $\left[\mathrm{CuBr}_{2}\right]^{-} 1.3 \cdot 10^{-6}$; $\lg \beta_{2}=8.85$ [8]

SP- solubility product of $\mathrm{CuBr}, 5.3 \cdot 10^{-9}$, $\operatorname{lgSP}=8.28$ [8]

$$
\begin{aligned}
\mathrm{E} & =E_{\text {oxid.agent }}^{0}-E_{\text {reduc.agent }}^{0} \\
& =0.05-(-0.09)=0.14 \mathrm{~V}>0
\end{aligned}
$$

\subsection{Reactions of precious metals in "aqua regia”}

Many students know that precious metals $\mathrm{Au}$ and $\mathrm{Pt}$ dissolve in ,aqua regia“:

$$
\begin{gathered}
\mathrm{Au}(\mathrm{s})+\mathrm{HNO}_{3}(\mathrm{l})+4 \mathrm{HCl}(\mathrm{l}) \stackrel{\text { conc. }}{\longrightarrow} \\
\mathrm{H}\left[\mathrm{AuCl}_{4}\right](\mathrm{aq})+\mathrm{NO}(\mathrm{g})+2 \mathrm{H}_{2} \mathrm{O}(\mathrm{l}) \\
3 \mathrm{Pt}(\mathrm{s})+4 \mathrm{HNO}_{3}(\mathrm{l})+18 \mathrm{HCl}(\mathrm{l}) \stackrel{\text { conc. }}{\longrightarrow} \\
3 \mathrm{H}_{2}\left[\mathrm{PtCl}_{6}\right](\mathrm{l})+4 \mathrm{NO}(\mathrm{g})+8 \mathrm{H}_{2} \mathrm{O}(\mathrm{l})
\end{gathered}
$$

Since the real conditions and the standard conditions differ due to many factors (e.g., temperature [12] and $\mathrm{pH}$ [13], concentrations of hydrogen and oxygen in the environment [13], etc.) the value of the potential is affected. Therefore, the adjustment range of electromotive force $\mathrm{E}^{0}$ of reactions [3] should be used:

It is believed that if $\mathrm{E}^{0}=\mathrm{E}_{\text {oxid. agent }}^{0}-\mathrm{E}_{\text {reduc. agent }}^{0}>0.4$ $\mathrm{V}$ the redox reaction proceeds to the end. If the value of $\mathrm{E}^{0}$ is in the range of $-0.4-+0.4 \mathrm{~V}$, under STP, the redox reaction takes place at low reaction rate. In practice such reactions are moving away from the standard conditions and the concentrated solutions of oxidizing and reducing agents must be applied (take the excess of oxidizing agent and a reducing agent, and, if possible, one of the reagents in the form of solid substances or gas). In such cases, the real potential of an oxidizing agent and a reducing agent decreases the potential, which leads to an increase in EMF. In addition, the increasing reaction power sometimes contributes to the increase of the temperature of the reaction mixture. If the $\mathrm{E}^{0}=\mathrm{E}_{\text {oxid. agent }}^{0}-\mathrm{E}_{\text {reduc. agent }}^{0}<-0.4$ $\mathrm{V}$, the forward reaction is thermodynamically impossible under any (standard or non-standard) conditions.

As an example, let us consider the Au dissolution in concentrated nitric acid and ,aqua regia“:

$$
\begin{array}{ll}
\text { 1. } & \mathrm{Au}(\mathrm{s})+6 \mathrm{HNO}_{3}(\mathrm{l}) \stackrel{\text { conc. }}{\longrightarrow} \\
\mathrm{Au}\left(\mathrm{NO}_{3}\right)_{3}(\mathrm{aq})+3 \mathrm{NO}_{2}(\mathrm{~g})+3 \mathrm{H}_{2} \mathrm{O}(\mathrm{l})
\end{array}
$$

Values of the standard potential $[9,10]$ are written:

$$
\begin{aligned}
& E^{o}\left(\mathrm{Au}^{3+} / \mathrm{Au}\right)=+1.50 \mathrm{~V} ; \\
& E^{o}\left(\mathrm{NO}_{3}^{-} / \mathrm{NO}\right)=+0.96 \mathrm{~V} \\
& E^{o}\left(\mathrm{NO}_{3}^{-} / \mathrm{NO}_{2}\right)=+0.87 \mathrm{~V} ; \\
& E^{o}\left(\left[\mathrm{AuCl}_{4}\right]^{-} / \mathrm{Au}\right)=+1.00 \mathrm{~V} .
\end{aligned}
$$

Calculation of EMF for the reactions:

$$
\begin{aligned}
\mathrm{E}_{1} & =E^{o}\left(\mathrm{NO}_{3}^{-} / \mathrm{NO}_{2}\right)-E^{o}\left(\mathrm{Au}^{3+} / \mathrm{Au}\right) \\
1 . \quad & =+0.87 \mathrm{~V}-(+1.498 \mathrm{~V}) \\
& =-0.628 \mathrm{~V} \\
\mathrm{E}_{2} & =E^{o}\left(\mathrm{NO}_{3}^{-} / \mathrm{NO}\right)-E^{o}\left(\left[\mathrm{AuCl}_{4}\right]^{-} / \mathrm{Au}\right) \\
2 . \quad & =+0.96 \mathrm{~V}-(+1.00 \mathrm{~V}) \\
& =-0.04 \mathrm{~V}
\end{aligned}
$$

On the basis of explanation [3] under standard conditions (STP), the $1^{\text {st }}$ reaction doesn't takes place, while the $2^{\text {nd }}$ reaction takes place.

Nitric acid in the solution "aqua regia" is needed for the production of chlorine from hydrochloric acid (nitrosyl chloride is a secondary product of this reaction):

$$
\begin{aligned}
& 2 \mathrm{HNO}_{3}(\mathrm{l})+6 \mathrm{HCl}(\mathrm{l}) \rightarrow 3 \mathrm{Cl}_{2}(\mathrm{~g})+2 \mathrm{NO}(\mathrm{g})+4 \mathrm{H}_{2} \mathrm{O}(\mathrm{l}) \\
& \mathrm{Cl}_{2}(\mathrm{~g})+2 \mathrm{NO}(\mathrm{g}) \rightarrow 2 \mathrm{NOCl}(\mathrm{g})
\end{aligned}
$$

Due to the high concentration of chloride ions in the solution "aqua regia", metals $\mathrm{Au}$ and $\mathrm{Pt}$ are bound to complex ions, which makes them more soluble because of the reduction of the electrodes potential:

$$
\begin{aligned}
& E^{o}\left(\mathrm{Au}^{3+} / \mathrm{Au}\right)>E^{o}\left(\left[\mathrm{AuCl}_{4}\right]^{-} / \mathrm{Au}\right)+1.498 \mathrm{~V}>+1.00 \mathrm{~V} \\
& E^{0}\left(\mathrm{Pt}^{2+} / \mathrm{Pt}\right)>E^{0}\left(\left[\left(\mathrm{PtCl}_{4}\right)\right]^{2-} / \mathrm{Pt}\right)+1.188 \mathrm{~V}>+0.73 \mathrm{~V} \\
& 3 \mathrm{Pt}(\mathrm{s})+4 \mathrm{HNO}_{3}(\mathrm{l})+18 \mathrm{HCl}(\mathrm{l}) \rightarrow \\
& 3 \mathrm{H}_{2}\left[\mathrm{PtCl}_{6}\right](\mathrm{l})+4 \mathrm{NO}(\mathrm{g})+8 \mathrm{H}_{2} \mathrm{O}(\mathrm{l})
\end{aligned}
$$

Values of the standard potential $[9,10]$ are written: 


$$
\begin{gathered}
E_{\text {oxid.agent }}^{0}=E^{0}\left(\mathrm{NO}_{3}{ }^{-} / \mathrm{NO}\right)=+0.96 \mathrm{~V} ; \\
E_{\text {reduc.agent }}^{0}=E^{0}\left(\mathrm{Pt}^{2+} / \mathrm{Pt}\right)=+1.188 \mathrm{~V} \\
E_{\text {reduc.agent }}^{0}=E^{0}\left(\left[\left(\mathrm{PtCl}_{4}\right)\right]^{2-} / \mathrm{Pt}\right)=+0.73 \mathrm{~V} ; \\
E_{\text {reduc.agent }}^{0}=E^{0}\left(\left[\left(\mathrm{PtCl}_{6}\right)\right]^{2-} /\left(\left[\left(\mathrm{PtCl}_{4}\right)\right]^{2-}\right)=+0.68 \mathrm{~V}\right.
\end{gathered}
$$

Calculation of EMF:

$$
\begin{gathered}
\mathrm{E}=E_{\text {oxid.agent }}^{0}-E_{\text {reduc.agent }}^{0} \\
=E^{0}\left(\mathrm{NO}_{3}{ }^{-} / \mathrm{NO}\right)-E^{0}\left(\mathrm{Pt}^{2+} / \mathrm{Pt}\right) \\
=+0.96 \mathrm{~V}-(+1.188 \mathrm{~V})=-0.228 \mathrm{~V} \\
\mathrm{E}=E_{\text {oxid.agent }}^{0}-E^{0}{ }_{\text {reduc.agent }} \\
=E^{0}\left(\mathrm{NO}_{3}{ }^{-} / \mathrm{NO}\right)-E^{0}\left(\left[\left(\mathrm{PtCl}_{4}\right)\right]^{2-} / \mathrm{Pt}\right) \\
=+0.96 \mathrm{~V}-(+0.73 \mathrm{~V})=+0.23 \mathrm{~V} \\
\mathrm{E}=E_{\text {oxid.agent }}^{0}-E^{0} \text { reduc.agent } \\
=E^{0}\left(\mathrm{NO}_{3}{ }^{-} / \mathrm{NO}\right)-E^{0}\left(\left[\left(\mathrm{PtCl}_{6}\right)\right]^{2-} /\left(\left[\left(\mathrm{PtCl}_{4}\right)\right]^{2-}\right)\right. \\
=+0.96 \mathrm{~V}-(+0.68 \mathrm{~V})=+0.28 \mathrm{~V}
\end{gathered}
$$

Based on the EMF value, it can be concluded that under standard conditions (STP) Pt forms complex ion $\left.\left[\mathrm{PtCl}_{6}\right)\right]^{2-}$ in “aqua regia”.

\section{Conclusions}

Calculation of electromotive forces for dissolution (oxidation-reduction) reactions of inactive and precious metals with acids allows students to systematize and expand knowledge about redox reactions in inorganic chemistry. When working in groups, students learned how to collaborate, calculate electromotive force (EMF) and predict a "thermodynamically favourable" reaction without performing an experiment.

\section{References}

[1] Sulcius, A. Reactions of Metals in Nitric Acid: Writing Equations and Calculating Electromotive Force of Redox Reaction. J. Chem. Edu., 2015, 92 (12), 1971-1972.

[2] Sulcius, A. Calculation of electromotive force in redox processes. World journal of chemical education, 2014, 2(2), 21-25.

[3] Lidin, R. A., Savinkina, E. V., Ruk, N. S., Alikperova, L. Ju., Tests of inorganic and general chemistry with solutions (In Russian), Binom, Moscow, 2010, p. 230.

[4] Hamman, C. H.; Hamnett, A.; Vielstich, W. Electrochemistry, 2nd ed.; Wiley-VCH: Hoboken, NJ, 2007; p 88.

[5] DeMeo, St. Does Copper Metal React with Acetic Acid? J. Chem. Educ., 1997, 74(7), 884-886.

[6] Massey, A. G. In Comprehensive Inorganic Chemistry; TrotmanDickenson, A. F., Ed.; Pergamon: London, 1973; Vol. 3, p 18.

[7] Tretjakov, A. Ju.; Martinenko, L. I.; Grigorjev, A. N.; Civadze, A. Ju. Inorganic chemistry: Chemistry of elements, V. 2, 2nd ed.; Moscow: MGU, 2007; p 670.

[8] Волков А. И., Жарский И. М. Большой химический справочник. Минск: Современная школа, 2005. - 608 с.

[9] Dobos, D. Electrochemical Data. A Handbook for Electrochemists in Industry and Universities; Kiado: Budapest, 1978; p 365.

[10] Rumiancev, B. V. Oxidation-reduction properties of elements and their compounds in solutions; Lanj: St. Petersburg, 2017; p 356.

[11] Rumiancev, B. V.; Usicenko, V. F. Redox Processes. Binom: Moscow, 2013; p 285.

[12] Yue, G.; Zhao, L.; Olvera, O.G.; Asselin, E. Speciation of the H2SO4-Fe2(SO4)3-FeSO4-H2O system and development of an expression to predict the redox potential of the $\mathrm{Fe} 3+/ \mathrm{Fe} 2+$ couple up to $150{ }^{\circ} \mathrm{C}$. Hydrometallurgy, 2014, 147-148, p.p. 196-209.

[13] Stransbury, E. E., Buchanan, R. A., Fundamentals of electrochemical corrosion, ASM International, Ohio, 2000; p. 489. 